Address: 1779 Massachusetts Ave., NW, Washington, D.C., 20036-2103, USA.

Website: http://www.carnegieendowment.org

President: Jessica T. Mathews.

\section{Carnegie Middle East Center}

Founded in 2006 as part of the Carnegie Endowment for International Peace's Middle East programme. Public policy think tank and research centre that aims to better inform the process of political change in the Arab Middle East and deepen understanding of the complex security and economic issues that affect it. Programmes: Middle East economies; Arab politics; regional relations; security.

Address: Lazarieh Tower, Building No 2026 1210, Fifth Floor, Emir Bechir St., Beirut, 11-1061 Riad El Solh, Lebanon. Website: http://www.carnegie-mec.org Director: Lina Khatib.

\section{Carnegie Moscow Center}

Founded in 1994 as a subdivision of the Carnegie Endowment for International Peace. Analyzes the most important issues in international affairs and Russian domestic and foreign policy, as well as the regions they affect. Programmes: economic policy; foreign and security policy; non-proliferation; religion, society and security; Russian domestic politics and political institutions; society and regions; the east-east: partnerships beyond borders.

Address: 16/2 Tverskaya, Moscow 125009, Russia.

Website: http://www.carnegie.ru

Director: Dmitry Trenin.

\section{Cato Institute}

Founded 1977. Non-profit public policy research foundation based on the principles of the American Revolution-limited government, free markets, individual liberty and peace. Comprises Centers for Constitutional Studies, Educational Freedom, Global Liberty and Prosperity, Representative Government and Trade Policy Studies.

Address: 1000 Massachusetts Ave., NW, Washington, D.C., 20001-5403, USA.

Website: http://www.cato.org

President: John A. Allison.

\section{Center for a New American Security}

Founded 2007. Leading research institution engaged in developing strong, pragmatic and principled national security and defence policies, and informing current and future security leaders. Research areas include: US national security and defence policy; regional security challenges; national security; US military forces and operations; terrorism, irregular warfare and crime; weapons of mass destruction and nuclear proliferation.

Address: 1152 15th Street, NW, Suite 950, Washington, D.C., 20005, USA.

Website: http://www.cnas.org

President: Richard Fontaine.

\section{Center for American Progress}

Founded 2003. Organization dedicated to improving the lives of Americans through progressive ideas and action. Research issues: domestic; economy; national security; energy and environment; media and progressive values.

Address: 1333 H St., NW, 10th Floor, Washington, D.C., 20005, USA.

Website: http://www.americanprogress.org

President: Neera Tanden.

\section{Center for International Governance Innovation}

Founded 2001. Independent, non-profit and non-partisan think tank that focuses on international governance. Research programmes: the global economy; the environment and energy; development; global security.

Address: 57 Erb St. West, Waterloo, Ontario, Canada N2L 6C2.

Website: http://www.cigionline.org

President: Rohinton Medhora.

\section{Center for Strategic and International Studies}

Founded in 1962 during the Cold War to find ways for the USA to sustain its prominence and prosperity as a force for good in the world. Bipartisan, non-profit organization that conducts research and analysis and develops policy initiatives that look into the future and anticipate change. Research focuses on defence and security, energy and climate change, global health, global trends and forecasting, governance, human rights, technology, and trade and economics.

Address: 1616 Rhode Island Ave., NW, Washington, D.C., 20036, USA.

Website: http://www.csis.org

President: John J. Hamre.

\section{Centre for Economic Policy Research}

Founded 1983. Non-profit, educational research network that promotes independent, objective analysis and public discussion of open economies and the relations among them. Programmes: development economics; financial economics; industrial organization; international macroeconomics; international trade and regional economics; labour economics; public policy.

Address: 77 Bastwick St., London EC1V 3PZ, UK.

Website: http://www.cepr.org

Director: Richard Baldwin.

\section{Centre for European Policy Studies}

Founded 1983. Independent institute specializing in European affairs. Research programmes: economic and social welfare policies; energy, climate change and sustainable development; EU neighbourhood, foreign and security policy; financial markets and institutions; justice and home affairs; politics and European institutions; regulatory policy; trade developments and agricultural policy.

Address: 1 Place du Congrès, B-1000 Brussels, Belgium.

Website: http://www.ceps.eu

Director: Daniel Gros.

\section{Centre for European Reform}

Pro-European think tank focusing on political, economic and social challenges facing Europe. Research topics: Britain and the EU; EU budget; EU foreign policy; EU institutions; justice and 